\title{
Medical ethics, teaching and the new genetics
}

\author{
Bob Williamson Murdoch Institute for Research into Birth Defects Ltd, Royal Children's Hospital, Melbourne, \\ Australia
}

We usually discuss how to use medicine to teach ethics, but since I started teaching molecular genetics to medical students over thirty years ago, I have been surprised at how little we use their keen interest in ethical issues as a motivator towards a better general understanding of how to provide excellent science-based medicine. I have been reluctant to offer my views on this, because I am neither a clinician nor an ethicist, but as the years go by I have become less worried that I might make mistakes (we all make mistakes) and more concerned to discuss what I think might lead to better practice.

In my experience, medical students (at least in Scotland, England and Australia) are unlike most other students in that virtually every one of them enters university an idealist, with the intention of behaving in an overtly ethical fashion. Indeed, as our editor said in his recent inaugural professorial address, "Medicine is a fundamentally moral pursuit". In this sense, it differs from science, or law, or fine arts - no one would say, for instance, of my own discipline that "Chemistry is a fundamentally moral pursuit". In my experience, students enter the medical course hungry for ethical meat. We give them (in most cases) anatomy, physiology and biochemistry.

In each department in which I have taught (Glasgow, St Mary's, London and Melbourne Universities, with occasional forays to the US and France) I have tried to move the teaching of human genetics to the beginning of the first term of the first year. I have also started the course with patients who have inherited disorders (and not with DNA nor with yellow and green peas). For medical students, ethical issues are best illustrated by people and their problems as they interact with health care professionals. Genetics is, at the moment, the perfect subject for teaching ethics to medical undergraduates.

Perhaps I can give a few examples of the way the issues come up. We discuss, for the most part, ethics and genetics equally. Genetics is the study of families. Who owns genetic data: the person tested, his or her parents, his or her children? What of employers, insurers, the community? We can now do the tests easily (in a matter of minutes, at little cost) - what are the implications of this? Do we have a duty of care, an obligation to go beyond what people request? Why should the child from age zero to sixteen be protected from genetic screening, and not the child before zero or after sixteen (or is it eighteen)?

Usually, we start with a clinical demonstration of someone with cystic fibrosis, thalassaemia or sickle cell disease. This has the great advantage that the "subject" is roughly the same age as the medical student. It is easy to forget, if one is pushing retirement as I am, that many of the students have never known anyone who has died below the age of 75 (ifo they know anyone who has died at all), and associate the problems of serious illness and death (around which many ethical dilemmas in medicine revolve) with the very old (for whom death can be seen as a natural end to a more or less fulfilled life). It has an additional advantage - it keeps a little spark of humanism alive at a time when the medical course is so often lacking in human contact.

We introduce cystic fibrosis through a young person with the disease, and then discuss confidentiality - within the family, with insurers and employers, between doctor and patient. An articulate young person with a life-long, life-threatening disease can put the case for an honest and thoughtful approach by the doctor [or doctor-in-training] to the patient much better than I can; on many occasions the young person with $\mathrm{CF}$ has argued that honesty with patients is what each has valued most from the best doctors, and dishonesty or a refusal to listen or answer questions is what each hates most. "Just listen to me - I am an individual just like you", as Sean (CF) shouted at our Melbourne students last month.

We talk about reproduction - should we assist someone who is bound to die (shortly) to have a child, and to what lengths do we go - do we help the woman with CF, who is only sub-fertile, and not the man, who has non-patent vas deferens? Do we approve of somatic gene therapy (well, everyone does for $\mathrm{CF}$, faced with a young person sitting in front of them), but what of germ line gene therapy for the couple I introduced to my students in May of 
this year, both of whom have CF and who want a child who does not have the disease? What of "improvement" by somatic gene therapy - how does this differ in ethics from cosmetic surgery? And this is before we even start on community screening for carriers, or breast cancer susceptibility genes such as BRCA1, or genes which lead to criminal behaviour (yes, there is one such mutation which has been validated, though it is fortunately very rare).

What I find most fascinating is how discussion of ethics transforms a class of children (with their animal noises and their paper airplanes) into a class of individual mature adults. I have now seen this so often, and for so many different teachers and patients (of variable verbal ability and emotional empathy), that I believe it is significant. This is partly because the students are so interested that it sparks the best from the teacher, but even more because most of the clinical demonstrations (that is, the patients) carry the discussion to the students in a way which makes the teacher almost irrelevant.

There is one other advantage in teaching ethics through the problems (and solutions) offered by "the new genetics". Often ethics is portrayed (sometimes deliberately and mischievously, more often in an attempt at contrast and to create interest) as representing an older, more caring concept of medical practice, in contrast to "scientific" or "high-tech" medicine. Since the scientific advances in molecular genetics have to be understood if sense is to be made of the ethical problems that arise, using genetic examples emphasises the unity of science, medicine and humanism. Ethics perpetrated in ignorance is prone to failure; it becomes a sort of "gestalt ethics" without roots in the realities of scientific clinical practice, and unable to meet new challenges easily. Far better to emphasise that proper scientific knowledge of the causes of disease, of the interactions between what we inherit and what we ourselves determine individually or socially, is the basis for proper, caring and ethical decision-making.

There is one problem I have not solved, which has become more apparent to me since I arrived in Melbourne. Like all Australian cities, we have a large number of recent Asian immigrants, mostly from South East Asian countries including Viet Nam, Laos, Cambodia, Hong Kong and China itself. Unlike students from other ethnic groups (including those from the Indian sub-continent, whom I am more familiar with from my experience in the UK), these seem to have little familiarity with the concept of autonomy as understood by those brought up in the European (Christian and associated) tradition. (Those from India understand the concept very well indeed, particularly in terms of the conflicts that arise between the autonomous individual and the powerful family/community pressure to behave in a particular way - indeed, it represents a very personal focus of experience for many of them.) Is this a real difference, or only a temporary hiccup in time, which will go in a generation or two at most?

The concepts that underlie the new genetics are remarkably simple to convey - once the student has mastered Crick and Watson, 23 pairs of chromosomes, meiotic recombination and person-specific PCR, all else can be left for later (to be explained as clinical-led studies require). I find that the essential concepts can be grasped by a year-one medical undergraduate class in about half an hour (they are, after all, among the brightest students whom most universities process). This means that many of the issues of medical ethics can be posed during the first term of the first year of the course, but in a real way, led by a patient and not a lecturer. Moreover, they can be examined in the way that is appropriate, as an integral part of questions of a scientific and clinical nature, rather than artificially and separately as if "ethics" is a subject rather like ENT or cardiology (or, for that matter, genetics).

I have taught almost entirely in the context of "traditional syllabuses" where there is little or no clinical contact with patients until students emergfo from the two- to three-year penance of the pre clinical course into what they perceive as the fascination of the clinical years. However, I understand from those who have taught human genetics in vertically integrated medical school courses (what might be called, for shorthand, the McMaster system) that the same thing occurs - except that the students welcome the discussions of ethical issues even more, as they have more of relevance to offer from their own experience.

Is this approach unusual? I came to it because I was neither a doctor nor an ethicist, and yet I had to teach medicine and ethics to my students. It works. It is interesting (the course gets alpha-plus for interest every time, even if other features do not score as high due to my own failings as a teacher). Perhaps most important, I have the satisfaction of meeting the students when they are house officers (residents) and registrars, and finding they still remember those patient-led ethics-focused molecular genetics clin dems of ten years or more before. There are lots of patients around who can help - why not give it a try?

Bob Williamson is Director of the Murdoch Institute for Research into Birth Defects Ltd, Royal Children's Hospital, Melbourne, 3052, Australia. 